\title{
Sosyal Medyadaki Dezenformasyon: 2021 Türkiye Orman Yangınları Örneği
}

\author{
Kadriye Kobak ${ }^{1}$
}

Başvuru Tarihi: 03.09 .2021 Yayın Kabul Tarihi: 06.12 .2021 Yayınlanma Tarihi: 30.12 .2021

Sakarya Üniversitesi, Iletişim Fakültesi,

Illetişim ve Tasarımı ve Medya Bölümü, Sakarya

kadriyekobak@sakarya.edu.tr

D) ORCID: 0000-0003-4909-416X

Şuheda Soğukdere ${ }^{2}$

Sakarya Üniversitesi, Sosyal Bilimler Enstitüsü, Iletişim Bilimleri Anabilim Dalı, Sakarya

suhedasogukdere@gmail.com

ORCID: 0000-0003-2227-2990

Öz

Türkiye Cumhuriyeti, 28 Temmuz 2021'de tarihinin en büyük orman yangını ile karşı karşıya kalmıştır. Yangınlar sonrasında ise sosyal medyanın çeşitli platformlarında doğrulanmamış çok sayıda bilgi ve görsel içerik üretilmiş ve bu içerikler birçok kişi tarafından paylaşılarak sosyal medyada sürekli dolaşıma sokulmuştur. Bu durumun yeni medya platformları ile teknolojilerinin günümüz sıradan kitlelerini, içeriği hem üreten hem de tüketen kullanıcılara dönüştürmüş olmasından ve de sosyal medyada dezenformasyonun yaygın görülmesinden kaynaklandığı düşünülmektedir.

Bu çalışmada 29 Temmuz - 11 Ağustos 2021 tarihleri arasında Türkiye'de çıkan yangınlarla ilgili sosyal medyada dolaşıma sokulan ve Teyit.org tarafından yalan/yanlış haber olduğu tespit edilen toplam 25 haber incelenmiştir. Veriler, doküman inceleme yöntemiyle toplanmış ve betimsel analiz ile irdelenmiştir. Araştırmanın sonuçlarına göre, en çok kullanılan dezenformasyon türü hatalı ilişkilendirme ve çarpıtmadır. Çalışmada dikkat çeken bir diğer husus da Teyit.org tarafından paylaşımları yaptığı tespit edilen hesapların büyük çoğunluğunun gerçek isim kullanmayan anonim hesaplardan yapılan paylaşımlar olmasıdır. Sosyal medyadaki bu dezenformasyona karşı medya okuryazarlığı çok büyük önem taşımaktadır.

Anahtar Kelimeler: Dezenformasyon, yalan haber, sosyal medya, medya okuryazarlığı, orman yangını.

1 Doktor Öğretim Üyesi

2 Yüksek Lisans Öğrencisi 


\title{
Disinformation in Social Media: The Case of 2021 Turkey Forest Fire
}

Application Date: 03.09.2021 Accepted Date: 06.12.2021 Publishing Date: 30.12 .2021

\author{
Kadriye Kobak ${ }^{3}$ \\ Sakarya University, Faculty of Communication, \\ Department of Communication Design and Media, Sakarya \\ kadriyekobak@sakarya.edu.tr \\ (iD) ORCID: 0000-0003-4909-416X \\ Şuheda Soğukdere ${ }^{4}$ \\ Sakarya University, Social Sciences Institute, \\ Department of Communication Sciences, Sakarya \\ suhedasogukdere@gmail.com \\ (iD) ORCID: 0000-0003-2227-2990
}

\begin{abstract}
On July 28, 2021, the Republic of Turkey faced the biggest forest fire in its history. New media platforms and technologies have transformed today's ordinary audiences into users who both produce and consume content. After the fires, a large number of unverified information and visual content was produced on various platforms of social media and shared by many people and constantly circulated.

In this study, a total of 25 news about the fires in Turkey, which were circulated on social media between 29 July and 11 August 2021, and which were determined to be false news/disenformation by Teyit.org, were examined. The data were collected by document analysis method and analyzed with descriptive analysis. According to the results of the research, the most commonly used type of disinformation is false association and distortion. Another point that draws attention in the study is that the majority of the accounts found to be shared by Teyit.org are from anonymous accounts that do not use real names. Media literacy is of great importance against this disinformation in social media.
\end{abstract}

Keywords: Disinformation, fake news, social media, media literacy, forest fire.

\footnotetext{
${ }^{3}$ Assistant Professor

4 Graduate Student
} 


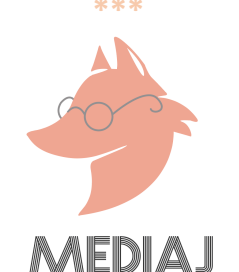

\section{GíRiş}

AFAD (Afet ve Acil Durum Yönetimi Başkanlığı) dünyada gözlenen ve biyolojik afetler kategorisinde değerlendirdiği orman yangınlarını, ülkemizde en sık görülen doğal afetlerden biri olarak kabul etmektedir (http1). Orman yangınlarının yıldırım düşmesi, elektrik hatları, yanardağ patlaması ve aşırı derecede yükselen hava sıcaklıkları gibi doğal olaylardan kaynaklanmasının yanısıra bilinçli ve bilinçsiz insan kaynaklı davranışları da bu duruma sebep olabilmektedir (Besli ve Tenekeci, 2020, s.900).

Türkiye Cumhuriyeti, 28 Temmuz 2021'de tarihinin en büyük orman yangını ile karşı karşıya kalmıştır. Antalya Manavgat bölgesinde başlayan, daha sonra ülkenin Akdeniz, Ege, Marmara, Batı Karadeniz ve Güneydoğu Anadolu bölgelerinde de görülen 299 orman yangını birçok canlıya ölümcül zararlar vermiş ve yerleşim yerlerinde önemli tahribatlara yol açmıştır (http2). Yangınlar sonrasında ise doğrulanmamış çok sayıda bilgi ve görsel içerik sosyal medyada paylaşılmış (http 3) ve bu paylaşımlar sabotaj iddiası, yakılan alanların yeniden imara açılacağına ilişkin kaygılar, terör şüphesi gibi konular ekseninde (http 4) sürekli ve yeniden tüketime sokulmuştur. Özellikle toplumsal çatışma, doğal afet ya da kriz dönemlerinde post-truth kavramına özgü olarak (Karakaş ve Doğru, 2021, s.165) uydurma, sahtelik, yanlışlık, yalan, aldatma, yanlış bilgilendirme, dezenformasyon, propaganda, komplo teorisi, hiciv (Andersen ve Søe, 2019) daha fazla üretilebildiği ve yayılabildiği öncül çalışmalarda belirtilmektedir.

\section{YALAN HABER/ YANLIŞ BİLGi}

Çevrimiçi platformlar, özellikle sosyal medya, doğasından gelen kolay erişim, daha ucuz ve hızlı yayılma gibi özellikleriyle giderek artan sayıda birey için ana haber kaynağı haline dönüşmüş (Shu, Wang ve Liu, 2018, s.430), sıradan kitleler hem haber üreten hem de haber tüketen topluluklara evrilmişlerdir (Karakaş ve Doğru, 2021, s.165). Bu durum yalan haberler, yanlış bilgiler için de yeni bir var olma ortamı doğurmuştur (Tandoc vd. 2018). Allcott ve Gen- tzkow (2017), yalan haberleri "kasten ve doğrulanabilir şekilde yanlış olan ve okuyucuları yanıltabilecek haber makaleleri" olarak tanımlamaktadır (s.213).

Sosyal medyada gerçekliğine dair herhangi bir kontrol yapılmadan paylaşılan bilgi bolluğu ile birlikte diğer kullanıcıların gerçekler ve önyargılar arasında ayrım yapmasını zorlaştırmakta; başlangıçta güvenilir görülen hikâyelerin zamanla yanlış veya uydurma olduğu kanıtlanmasına rağmen; yanlış oldukları kanıtlanana kadar, geri döndürülemez hasarlara neden olabilmektedir (Naeem ve Bhatti, 2020, s.1). Wardle (2017) "yalan haber" teriminin tüm bilgi ekosistemiyle ilgili olduğunu ve yanlış teriminin, farklı yanlış bilgi türlerinin (yanlış bilginin kasıtsız olarak paylaşılması) ve dezenformasyonun (yanlış olduğu bilinen bilgilerin kasıtlı olarak oluşturulması ve paylaşılması) karmaşıklı̆ını anlamaya çalışmıştır. Bu süreçte araştırmacı, bilgi ekosisteminde yedi içerik türünün olduğunu ileri sürmektedir. Bunlar, zarar verme niyeti olmayan, ancak kandırma potansiyeli olan hiciv veya parodi; bir konuyu veya kişiyi çerçevelemek için bilgilerin yanıltıcı kullanımı olan yanıltıcı içerik; asıl kaynakların taklit edilmesi ile oluşan sahte içerik; tamamen aldatmak ve zarar vermek için tasarlanan uydurulmuş içerik; başıklar, görseller veya alt yazılar içeriği desteklemediğinde oluşan yanlış bağlantı; orijinal içerik yanlış bağlamsal bilgilerle paylaşıldığında oluşan yanlış bağlam ve gerçek bilgiler veya görüntülerin manipüle 


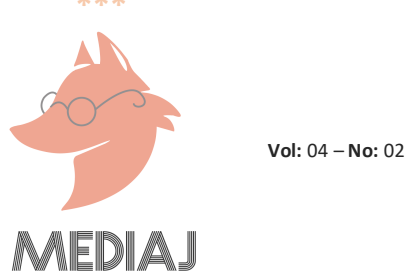

edilmiş yanlış bağlamsal bilgilerle paylaşıldığında oluşan manipüle edilmiş içeriktir. Tandoc v.d. (2018) ise yalan haber özelinde kavramın tanımlanmasına dair yapılmış makaleleri incelemişler ve yalan haberi hiciv, haber parodisi, fabrikasyon/uydurma, manipülasyon, reklam ve propaganda olmak üzere altı türde toplamışlardır. Bahsedilen türler içinde misenformasyon ve dezenformasyona ayrıntılı olarak yer vermek çalışma bütünü açısından önem taşımaktadır (s.11).

Misenformasyon ve dezenformasyon, ekonomi, eğitim, güvenlik, sağlık, sanayi, enerji, spor, güvenlik, iç politika ve uluslararası ilişkiler gibi alanlarda, bir nevi toplumun ilgisini çeken, güncel konularda olabilmektedir (Bahar, 2020, s.2766). Bu denli içeriklerin yayılmasında post-truth kavramına gönderme yapmak gerekmektedir. Post-truth, "kamuoyunun şekillenmesinde objektif gerçeklerden ziyade duyuların ve kişisel inancın daha etkili olduğu" şeklinde tanımlanmaktadır (http 5). Güven (2019) insanların, kendileri gibi düşünen ve inanan kişilerin kanaatlerini, hakikatin tam aksi bile olsa, kabul etmeye yatkın olduklarını, bir diğer deyişle insan davranışının irrasyonel zeminde manipülasyona müsait olduğunu Freud'un görüşlerine dayanarak açıklar (s.21).

Vosoughi, Roy ve Aral (2018), Twitter'da 2006'dan 2017'ye kadar dağıtılan tüm doğrulanmış doğru ve yanlış haber hikayelerinin diferansiyel dağılımını araştırdıkları çalışmalarında, yanlışığın daha hızlı, daha derine ve daha geniş bir şekilde yayıldığını, gerçek haberlere göre daha yeni olarak algılandığını tespit etmişlerdir. Araştırmacılar, sahte hikayelere korku, iğrenme ve şaşkınlık; gerçek hikayelere ise beklenti, üzüntü, neşe ve güven gibi duygusal tepkilerin verildiğini saptamışlar; bunun yanı sıra yalan haberin yayılmasında insanların robotlardan daha hızlı olduğunu dile getirmişlerdir. Reed (2001) bu durumu açıklarken internetin bir ağlar ağı olduğunu ve değerinin sağladığı bu bağlantılardan gerçekleştiğini ifade etmiştir. Düşünüre göre, ağ üyelerinin iletişim grupları oluşturmasını ve sürdürmesini sağlayan şey, çoktan çoğa veya gruba doğru oluşturan ağdır. Bir yayın ağındaki kullanıcı sayısı arttıkça, değeri doğrusal bir şekilde artmaktadır. Ağ ne kadar büyük olursa olsun, her yeni üye aynı miktarda değer katmaktadır. İşlemsel bir ağda değer çok daha hızlı büyümekte; her yeni üye, diğer tüm üyeler için mevcut olan potansiyel bağlantıların sayısını arttırdığından, ağ genişledikçe her üyenin değeri de yükselmeye devam etmektedir. E-posta ve anlık mesajlaşma buna örnek gösterilebilmektedir. Aslında bu durum van Dijk'in bir bağlantı kültürü dediği şeyi başka bir deyişle bağlanma, içerik paylaşma ve dağıtma dürtüleri göz önüne alındığında, sosyal medya platformlarının salt varlığını ortaya koymaktadır (Aktaran:Andersen ve Søe, 2019).

Shu vd. (2020) sahte haberlerin yayılmasında kötü niyetli hesapların sosyal botların, trollerin de rol oynadığını; sosyal botlar ile bilginin oldukça popüler ve birçok kişi tarafından onaylandığı gibi yanlış bir izlenim verdiğini ifade etmektedir. Bu aşamada Kavaklı (2019) sosyal medyada manipülatif bilginin güç kazanmasında filtre baloncukları ve yankı odalarının da etkili olduğunu ileri sürmektedir (s.668). Sosyal medya sitelerinin perde arkasında algoritmik olarak çalışan filtre baloncukları, kullanıcıların bu platformlarda geçirdikleri süreyi arttırmak amacıyla kullanıcıları kabul edilebilir içeriklere maruz bırakmakta ve medya, kullanıcılara benzer düşünen bireyleri takip etme yeteneği vererek, son derece kişiselleştirilmiş yankı odalarının oluşturulmasına neden olmaktadır (Rhodes, 2021). Yankı odalarında sonuçta "herkes seninle hemfikir, herkes her şeyi göze almaya değer ya da aksi görüşler yanlı, yanlış bilgilendirilmiş, iddiaları ise kesinlikle ciddiye almaya değmeyen" bir algı oluşmaktadır (Elzinga, 2021, s.41). 


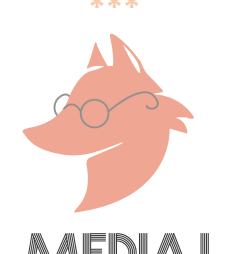

\section{MEDIAJ}

Geeng, Yee ve Roesner (2020) çalışmalarında kullanıcıların, Facebook ve Twitter'da karşılaştıkları yanlış bilgilerle nasıl etkileşime girdiklerine, çevrimiçi bilgileri nasıl tüketip paylaştıklarını araştırmışlardır. Araştırmacılar, sosyal medya kullanıcılarının yanlış gönderiler dahil olmak üzere, yayınlarındaki birçok gönderiyi derinlemesine okumadan kaydırdıklarını tespit etmişlerdir. Uzun metinlerle veya videolarla tam etkileşimde bulunmaktan kaçınan, ekstra zaman harcamak istemeyen bu kişilerin kısa metin veya videolar dikkatlerini daha çok çekmektedir. Katılımcıların gönderilerin içeriğini olduğu gibi kabul ettiğini ve bunun doğru olup olmadığı konusunda herhangi bir şüphe duymadıklarını, genellikle de bu güvenin temel nedeninin, içeriği yayınlayan kişiye duyulan güven ve/veya gönderinin siyasi görüşleriyle uyumlu olmasından kaynaklandığı saptanmıştır.

Yanlış bilgi/ yalan haber karşısında haberlerde yer alan iddiaları araştırmak amacıyla "gerçekliğin kontrolü- fact-checking-" adı altında sosyal medya çalışmaları başlamıştır (Krause vd., 2020, s.1053). Doğrulama yapan web siteleri periyodik olarak yeni gelen haber makalelerini güncellediğinden (Shu, vd.,2020), yeni medyada tehlike/tehditler olarak görülen sahte habere/bilgiye karşı doğrulama ile kamuoyunun bilme hakkı sağlanabileceği düşünülmektedir (Karadağ ve Ayten, 2020, s.485).

Doğrulama çalışmaları yürüten Snopes.com, CheckYourFact.com, ve FactCheck.org gibi yabancı platformların yanı sıra, Türkiye'deki başlıca doğruluk kontrol platformları YalanSavar.org, Malumatfurus.org, EvrimAgaci.org, DogrulukPayi.com, Teyit.org, gununyalanları.com, FactCheck.TR, Dogrula.org yer almaktadır (Ünver, 2020).

$\mathrm{Bu}$ grup içerisinde Teyit.org, Uluslararası Doğruluk Kontrol Ağı'nın prensiplerine uyan ve çalışmalarında tarafsız olduğunu, hakkaniyetli davrandığını, kaynaklarının, finansal yapısının ve organizasyonunun şeffaf olduğunu, metodolojisinin herkese açık şekilde paylaşıldığını ve düzeltme politikasını yayınladığını ağ'ın yönetim kuruluna ve bağımsız değerlendiriciye ispat ederek işleyişini sürdüren önemli bir platformdur. "Teyit.org" doğrulama platformu aslında yeni medyanın bir nevi eşik bekçiliğini yapmaktadır (Yolçu, 2018). Bu aşamada Uluslararası Doğrulama Ağı'nın öneminden bahsetmek gerekmektedir.

Uluslararası Doğrulama Ağı 2015'te Florida ABD'de kurulmuştur. Poynter Medya Çalışmaları Enstitüsü bünyesindeki kuruluşun amacı tüm dünyadaki doğrulama platformlarını bir araya getirerek, bu platformlara belli bir standardizasyon ve hesap verilebilirliklerini sağlamaktır. Ünver'in (2020) araştırmasına göre, “Doğrulama platformları Doğruluk Kontrol Ağı'na üye olabilmek için ekiplerinin tam listesini, geçmiş doğrulama performanslarının detaylı bir dökümünü ve finansal yapılarını dış hakemlerin denetimi ve gözetimine açık hale getirirler. Anonim dış hakemler, bu platformların başvurusunu tecrübe, finansal şeffaflık, takım yetkinlik ve büyüklüğü, ve doğrulama pratiklerindeki yöntemin açıklanabilirliği kriterlerine göre değerlendirirler. Bu süreçten başarılla geçen platformlar hem doğrulama konusundaki yetkinlikleri, hem de bilgilerinin topluma açık kalkması hususlarında kendilerini kanıtlamış sayılırlar."

Türkiye'de yalan, asılsız haberlerin ya da paylaşımların sosyal medyada yayılmasının araştırıldığı çeşitli çalışmalar bulunmaktadır. Ayhan ve Erkan (2018) seçim dönemlerinde daha da artan 


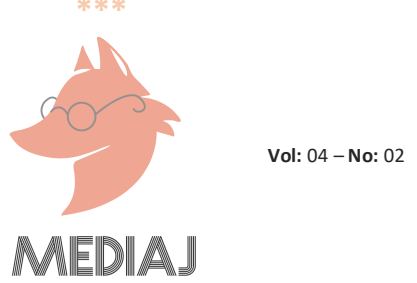

dezenformasyon amacıyla üretilmiş sosyal medya paylaşımlarını doğrulama platformu olan teyit.org üzerinden inceleyerek yalan enformasyonların önlenmesinde doğrulama platformlarının işlevini irdelemişlerdir (s.219). Çalışmada sosyal medya mecralarının yalan haberin üretimi ve yayılımında etkili olduğu saptanırken, toplumun doğru bilgiye ihtiyaç duyduğu kritik zamanlarda yalan haberin daha da fazla yayıldığı sonucuna varılmıştır. Araştırmacılar bilinçli bir şekilde dezenformasyon yapmak niyetinde olmayan bireylerin, kaynak doğrulama veya bilginin doğruluğundan emin olmadan paylaşım yapmama gibi kaygılarının olmadığını bulgulamışlardır.

Ünal ve Taylan (2017) tarafından yapılan bir başka çalışmada ise sağlık iletişimi ele alınarak sosyal paylaşım ağlarında dolaşıma sokulan sağlıkla ilgili içerikler Teyit.org üzerinden incelenmiştir. Bu araştırmada da Teyit.org'da incelenen ve toplumun büyük bölümünü ilgilendiren sağlık haberlerinin asılsız olduğu, toplumu yanlış yönlendirdiği görülmüştür. Özellikle güvenilir olduğu kabul edilen medya kuruluşlarının insanlar üzerindeki etkisinin daha fazla olmasından dolayı yalan haberin inandırıcılı̆ı artabilmektedir.

Çömlekçi'nin (2019) araştırmasında ise, doğrulama platformlarının etkisine değinilmiştir. Sosyal medyada dolaşıma giren yalan haberi tespit etmek kadar önemli olan bir konu da doğrulama platformları tarafından yalan olduğu netleştirilmiş içeriğin, yalan haberin ulaştığı kadar çok kullanıcıya ulaşamamasıdır. Doğrulama platformlarının etkisi konusu da gelecek çalışmalarda değerlendirilmesi gereken bir problem olmaktadır.

Aydın’nın (2020) araştırması ise pandemi sürecindeki bilgi kirliliği üzerine olmuş, yine toplumsal bir kriz anında yalan haberlerin yayılmasının yarattığı tahribata değinmiştir. Böyle bir çalışmanın ortaya çıkması da bize kriz anlarında doğruya bilgiye ulaşma isteğinin ne kadar arttığını, fakat buna paralel olarak da bilgi kirliliğinin de arttığını göstermektedir. Bu çalışmada WhatsApp gibi kapalı mesajlaşma uygulamalarının da dezenformasyon da büyük rol oynadığı görülmüştür. WhatsApp gibi bir uygulamanın diğer sosyal medya mecralarına kıyasla daha kişisel olduğu ve daha yakın kişilerle iletişim kurmayı sağladığı düşünüldüğünde burada yayılan yanlış bilgi "tanıdıklardan" geldiği için daha inandırıcı olabilme ihtimali bulunmaktadır.

\section{MEDYA OKURYAZARLIĞı}

Medya okuryazarlığı, televizyon, video, sinema, reklamlar ve internette bulunan içerikler gibi yazılı ve yazılı olmayan farklı türlerdeki iletilere erişim, onları çözümleme, değerlendirme ve iletme yeteneği olarak tanımlanmaktadır (İnceoğlu, 2007, s.21). Medyada bulunan iletilerin tümünün kurgu olduğu ve insanın gördüklerini gerçek olarak değerlendirme davranışı düşünüldüğünde; medya okuryazarlığı becerisinin medya iletilerine maruz kalınan yaşlardan itibaren başlanması gerekliliği ortaya çıkmaktadır. Kişilerin medya mesajlarının içeriğini anlaması, bu içerikleri doğru analiz edebilmesi ve içeriği değerlendirebilmesi yaşam boyu devam eden kültürel bir süreç olarak karşımıza çıkmaktadır (Karaduman, 2019, s.686). Medya içerikleri içinde bulunulan sosyal, ekonomik ve teknolojik olanakların da etkisiyle değişebilmektedir. Bu nedenle medyanın değişim ve gelişimiyle doğru orantılı olarak medya okuryazarlığı bilinci de sürekli olmalıdır. Yukarıda da bahsi geçen post-truth çağının başlaması bilgiyi çeşitlendirmiş, dolayısıyla da doğru bilgiye erişimin zorlaşması medya okuryazarlığı bilincinin geliştirilmesini 


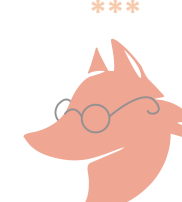

\section{MEDIAJ}

önemli hale getirmiştir. Bilgi, aşırı çeşitlenmesinin sonucu olarak geleneksel değerini kaybetmeye başlamış, medya okuryazarlığı ise bu noktada kişilerin bilgi kaynaklarını araştırmasını, farklı kaynaklardan faydalanılması gerekliliğini ve en önemlisi bilgiye eleştirel yaklaşma farkındalığını amaç edinmiştir (Çimen, 2020, s.127).

Günümüzde gelinen noktada medya okuryazarlığı yerini yeni medya okuryazarlığına bırakmaktadır. Yeni medya okuryazarlığı becerisi, geleneksel medya okuryazarlığı becerisini temel alarak şekillenmektedir. Iletişimin artık neredeyse tamamen yeni medya mecraları aracılığıyla gerçekleşmesi hem yeni medya okuryazarlığını kavramını literatüre eklemiş, hem de yeni medya mecralarının kullanım yaygınlığı göz önüne alındığında kaçınıımaz bir beceri haline gelmiştir. Kullanıcıların bu mecralarda aktif, üretici ve katılımcı pozisyonda olması, geleneksel medya okuryazarlığı becerilerinin yanına bir takım yeni becerilerin de eklenmesini gerekli kılmıştır (Karaduman, 2019, s.686).

Yeni medya okuryazarlığı becerisinin geliştirilmesini gerekli kılan önemli faktörler arasında etik sorunlar ve bilgi kirliliği yer almaktadır. Yeni medya teknolojileri sayesinde günlük rutinlerimizin bir parçası olan, sosyal ağlar kişiler arası iletişim modellerinden, haber alışverişimize ve iş yapış biçimlerimize kadar pek çok alanda etkili olmaktadır. Üreticilerle tüketiciler arasındaki sınırların silikleştiği bu ortamda üretilen pek çok içerik kamusaldır ve bu durumun ortaya koyduğu birtakım sonuçlar zaman zaman farklı görünümlerle karşımıza çıkmaktadır (Sezen, 2011, s.167). Tüm bu gelişmelerin sonucunda yeni medya ortamlarının gerek içerik üretiminde sağladığı serbestlik, gerekse bilgi ve içeriğe ulaşma yollarının çeşitliliği, kullanıcıların sahip olması gereken yetkinlikler konusunda yeni başlıkları gündeme getirmiştir (Posos Devrani, 2020, s.27). Yeni medya okuryazarlığı becerileri çeşitli kaynaklar tarafından sağlanan enformasyon akışı içinde hem doğru bilgiye ulaşmayı, hem manipüle edilmemeyi hem de bireylerin kendi filtre baloncukları içinde hapsolmamasını sağlayacaktır.

\section{YÖNTEM}

Türkiye'de 2021 yılında çıkan orman yangınlarını medya okuryazarlığı bağlamında analiz etmeyi amaçlayan bu çalışmada veriler, doküman inceleme yöntemiyle toplanmış ve betimsel analiz ile irdelenmiştir.

Doküman incelemesi, araştırılması hedeflenen olgu veya olgular hakkında bilgi içeren yazılı materyallerin analizini kapsamaktadır. Hangi dokümanların önemli olduğu ve veri kaynağı olarak kullanılabileceği araştırma problemi ile ilgili olmaktadır (Yıldırım ve Şimşek, 2006, s.185-186). Günümüzde doküman analizinde veri olarak çevrim içi kaynaklar da kullanılabilmektedir (Sak, Sak, Şendil ve Nas, 2021). Doküman incelemesine dayalı araştırmalarda, tüm doküman verisinin bir bütün olarak analize konu olması mümkün olmayabilir; bu nedenle eldeki veri setinden bir örneklem oluşturmak gerekebilir (Yıldırım ve Şimşek, 2006, s.197-198).

Araştırmanın çalışma grubu belirlenirken amaçlı örnekleme yöntemlerinden ölçüt örnekleme tercih edilmiştir. Bu örnekleme yönteminde önceden belirlenmiş bir dizi ölçütü karşılayan durumların çalışılması söz konusu olabilmektedir (Yıldırım ve şimşek, 2006, s.112). İlgili araştırmada örneklem grubunu Teyit.Org platformundan alınan 25 haber oluşturmaktadır. 
Buradaki sınırlama ve ölçüt iletilerin sosyal medyada dolaşıma sokulması, Türkiye'de çıkan orman yangınlarıyla ilgili ve 29 Temmuz - 11 Ağustos 2021 tarihleri arasında olması, ayrıca Teyit.org tarafından yalan/yanlış haber olduğu kabul edilmesidir.

Türkiye'de faaliyet gösteren başlıca doğruluk kontrol platformları; Yalansavar.org, Malumatfurus.org, EvrimAgaci.org, DogrulukPayi.com, Teyit.org, gununyalanlari.com, factcheckingturkey.com, Dogrula.org'dir (Ünver, 2020). Bu platformların tamamı doğruluk kontrol platformları olsa da aralarında çalışma alanı olarak farklar bulunmaktadır. Örneğin Malumatfuruş adlı organizasyon incelendiğinde kuruluş amaçlarının ve çalışma alanlarının köşe yazarlarının yazdığı yazıların doğruluğunu kontrol etmek olduğu görülmektedir (http 6). Doğruluk Payı adlı kuruluş, Uluslararası Doğruluk Kontrolü Ağı'na üye olmakla birlikte, çalışma alanı siyasi partilerin seçim vaatlerini, siyasetçilerin demeçlerini, gündeme ilişkin konuları doğrulamak olarak açıklamış, hedefini siyasi okur yazarlığı kazandırmak olarak belirlemiştir (http 7). Yalan Savar ve Evrim Ağacı gibi kuruluşlar da bilimsel bilginin doğruluğunu kontrol etmek ve sözde bilim iddialarını çürütmek amaçlı çalışmalar sürdürmektedirler (Ünver, 2020, s.5). Bu çalışmada hem Uluslararası Doğrulama Ağı'na üyeliği, hem de çalışma amacı olarak dijital okuryazarlık ve sosyal medyada çıkan haberlere eleştirel bakabilme becerisinin geliştirilmesini hedeflenmesinden dolayı araştırmada örneklem seçimi bakımından Teyit.org'nin içerikleri uygun görülmüştür.

Çalışmada 2021 orman yangınları ile ilgili sosyal medyada dolaşıma girmiş ve yalan olduğu Teyit.org tarafından belirlenmiş haberlere yer verilmiştir. Bu haberler habere verilen başlık, haberin tarihi, haberin aslı, dezenformasyon türü, paylaşımın yapıldığı mecra ve etkileşim sayıları açısından incelenmiştir. Paylaşılan mecra ve etkileşim sayısı olarak verilen bilgiler ve sayısal değerler, Teyit.org editörleri tarafından tespit edilen bilgilerdir. Sosyal paylaşım sitelerinde bir gönderiyi paylaşmış ve beğenmiş olan her kullanıcıya ulaşmak mümkün olmadığından ya da kullanıcı yaptığı işlemi silebildiğinden, çalışma kuruluşun saptadığı verilerle sınırı tutulmuştur.

\section{BULGULAR}

Çalışmada orman yangınlarına dair yapılmış olan dezenformasyon içeriklerin analizleri şu şekildedir.

Tablo 1. Dezenformasyon Türleri

\begin{tabular}{|c|c|c|c|c|c|c|}
\hline İddia & Tarih & Haberin Aslı & $\begin{array}{l}\text { Dezenformasyon } \\
\text { Türü }\end{array}$ & $\begin{array}{l}\text { Paylaşım } \\
\text { Tespiti / } \\
\text { Mecra }\end{array}$ & $\begin{array}{l}\text { Etkileşim } \\
\text { Sayısı }\end{array}$ & $\begin{array}{l}\text { İletinin } \\
\text { Geçtiği } \\
\text { Ortam }\end{array}$ \\
\hline $\begin{array}{l}\text { Videonun } \\
\text { Türkiye'deki } \\
\text { yangınların } \\
\text { kundaklama } \\
\text { olduğunu } \\
\text { gösterdiği } \\
\text { iddiası }\end{array}$ & $29 / 07 / 2021$ & $\begin{array}{l}\text { Video } 2020 \\
\text { yılı Ağustos } \\
\text { ayında } \\
\text { yangınla } \\
\text { mücadelede } \\
\text { önemli bir } \\
\text { yöntem olan } \\
\text { "planlı" } \\
\text { yakma }\end{array}$ & $\begin{array}{l}\text { Hatalı } \\
\text { illişkilendirme }\end{array}$ & $\begin{array}{l}\text { @CemilCan5 } \\
834, \\
25 / 07 / 2021\end{array}$ & $\begin{array}{l}1.135 \\
\text { etkileşim }\end{array}$ & Twitter \\
\hline
\end{tabular}




\section{MEDIAJ}

\begin{tabular}{|c|c|c|c|c|c|c|}
\hline & & $\begin{array}{l}\text { operasyonu } \\
\text { nu } \\
\text { gösteriyor. }\end{array}$ & & & & \\
\hline $\begin{array}{l}\text { Türkiye'de } \\
28-29 \\
\text { Temmuz } \\
\text { tarihlerinde } \\
\text { çıkan } \\
\text { yangınlardan } \\
\text { olduğu } \\
\text { imasıyla } \\
\text { paylaşılan } \\
\text { bir videoda } \\
\text { gözüken } \\
\text { kişilerin, } \\
\text { orman } \\
\text { yangınını } \\
\text { başlattıkları } \\
\text { iddia edildi. }\end{array}$ & $30 / 07 / 2021$ & $\begin{array}{l}\text { Video } 2020 \\
\text { yılından ve } \\
\text { Irak'ın } \\
\text { kuzeyinde } \\
\text { çekilmiş. } \\
\text { Anadolu } \\
\text { Ajansı } \\
\text { haberinin } \\
\text { orijinaline } \\
\text { ajansın } \\
\text { internet } \\
\text { sitesi } \\
\text { üzerinden } \\
\text { ulaşılabiliyor }\end{array}$ & $\begin{array}{l}\text { Hatalı } \\
\text { iliş̧ilendirme }\end{array}$ & $\begin{array}{l}\text { Hakan Bilal } \\
\text { Kutlualp, } \\
29 / 07 / 2021 \\
\text { Mehdi } \\
\text { Anlaroğlu, . } \\
29 / 07 / 2021 \\
\\
\text { Ipek Mat } \\
\text { Bayraktar } \\
\text {,29/07/2021 }\end{array}$ & $\begin{array}{l}\begin{array}{l}1.258 \\
\text { etkileşim }\end{array} \\
\begin{array}{l}1.332 \\
\text { etkileşim }\end{array} \\
387 \\
\text { etkileşim }\end{array}$ & $\begin{array}{l}\text { Twitter } \\
\text { Twitter }\end{array}$ \\
\hline $\begin{array}{l}\text { Sosyal } \\
\text { medyada } \\
\text { paylaşılan } \\
\text { alevlerin } \\
\text { arasındaki } \\
\text { atlar } \\
\text { fotoğrafının } \\
\text { Türkiye'de } \\
\text { birçok ilde } \\
\text { aynı anda } \\
\text { çıkan } \\
\text { yangınlardan } \\
\text { olduğu iddia } \\
\text { edildi. }\end{array}$ & $30 / 07 / 2021$ & $\begin{array}{l}\text { Fotoğraf } 21 \\
\text { Aralık } 2019 \\
\text { tarihinden } \\
\text { ve } \\
\text { Avustralya'd } \\
\text { an. } \\
\text { Fotoğrafın } \\
\text { orijinaline } \\
\text { Australian } \\
\text { AP } \\
\text { arşivinden } \\
\text { erişilebiliyor. }\end{array}$ & $\begin{array}{l}\text { Hatalı } \\
\text { Illişkilendirme }\end{array}$ & $\begin{array}{l}\text { @biidurunb } \\
\text { eee, } \\
30 / 07 / 2021\end{array}$ & $\begin{array}{l}4.000 \\
\text { etkileşim } \\
\text { aldı. }\end{array}$ & Twitter \\
\hline $\begin{array}{l}\text { Manisa'da } \\
\text { gözaltına } \\
\text { alınan iki } \\
\text { kişinin } \\
\text { orman } \\
\text { yangınlarıyla } \\
\text { ilişkili } \\
\text { olduğunun } \\
\text { belirlendiği } \\
\text { iddiası }\end{array}$ & $30 / 07 / 2021$ & $\begin{array}{l}\text { Manisa } \\
\text { Valiliği } \\
\text { gözaltına } \\
\text { alınan } \\
\text { kişilerin } \\
\text { orman } \\
\text { yangınlarıyla } \\
\text { ilgisi } \\
\text { olmadığını } \\
\text { açıkladı. }\end{array}$ & $\begin{array}{l}\text { Hatalı } \\
\text { ilişkilendirme }\end{array}$ & $\begin{array}{l}\text { Sputnik } \\
\text { Türkiye, } \\
\text { 29/07/2021 } \\
\text { Pushholder, } \\
\text { 29/07/2021 } \\
\text { Vaziyet, } \\
\text { 29/07/2021 } \\
\text { Ibrahim } \\
\text { Haskoloğlu, } \\
\text { 29/07/2021 }\end{array}$ & $\begin{array}{l}\begin{array}{l}331 \\
\text { etkileşim }\end{array} \\
46.000 \\
\text { etkileşim } \\
6.790 \\
\text { etkileşim } \\
5.310 \\
\text { etkileşim } \\
\text { 3.950 } \\
\text { etkileşim }\end{array}$ & Twitter \\
\hline
\end{tabular}




\begin{tabular}{|c|c|c|c|c|c|c|}
\hline & & & & $\begin{array}{l}\text { Hype, } \\
\text { 29/07/2021 } \\
\text { Leon, } \\
\text { 29/07/2021 } \\
\text { TRT Haber, } \\
\text { 29/07/2021 } \\
\text { Misvak Caps, } \\
\text { 29/07/2021 } \\
\text { Türk'e dair, } \\
\text { 29/07/2021 } \\
\text { İnci Sözlük, } \\
\text { 29/07/2021 } \\
\text { BPT, . } \\
\text { 29/07/2021 }\end{array}$ & $\begin{array}{l}\begin{array}{l}3.250 \\
\text { etkileşim }\end{array} \\
159 \\
\text { etkileşim } \\
1.730 \\
\text { etkileşim } \\
4.210 \\
\text { etkileşim } \\
1.815 \\
\text { etkileşim } \\
\text { 3.089 } \\
\text { etkileşim }\end{array}$ & $\begin{array}{l}\text { Twitter } \\
\text { Twitter } \\
\text { Twitter } \\
\text { Twitter } \\
\text { Twitter } \\
\text { Twitter } \\
\text { Twitter }\end{array}$ \\
\hline $\begin{array}{l}\text { Traktör } \\
\text { sürücüsünün } \\
\text { yangını } \\
\text { engellediği } \\
\text { görüntülerin } \\
\text { Türkiye'de } \\
\text { devam eden } \\
\text { yangınlardan } \\
\text { olduğu } \\
\text { iddiası }\end{array}$ & $30 / 07 / 2021$ & $\begin{array}{l}2013^{\prime} \text { te } \\
\text { Colorado'da } \\
\text { ki Weld'de } \\
\text { çıkan } \\
\text { yangından. } \\
\text { Videonun } \\
\text { orijinalini } \\
\text { CBS } \\
\text { Denver'da } \\
\text { görebiliyoru } \\
\text { z }\end{array}$ & $\begin{array}{l}\text { Hatalı } \\
\text { ilişskilendirme }\end{array}$ & $\begin{array}{l}\text { MrAcar1905 } \\
, 29 / 07 / 2021 \\
\\
\text { PratikDunya, } \\
28 / 07 / 2021 \\
\\
\text { IYI1INSAN_, } \\
29 / 07 / 2021 \\
\\
\text { bsgokdemir, } \\
\text { 29/07/2021 }\end{array}$ & $\begin{array}{l}10 \text { etkileş } \\
\text { im } \\
11.884 \\
\text { Etkileşim } \\
6.981 \\
\text { etkileşim } \\
34 \text { etkileş } \\
\text { im }\end{array}$ & $\begin{array}{l}\text { Twitter } \\
\text { Twitter } \\
\text { Twitter } \\
\text { Twitter }\end{array}$ \\
\hline $\begin{array}{l}\text { Yangında } \\
\text { hayatını } \\
\text { kaybeden } \\
\text { anne kuş } \\
\text { fotoğrafının } \\
\text { Türkiye'den } \\
\text { olduğu } \\
\text { iddiası }\end{array}$ & $02 / 08 / 2021$ & $\begin{array}{l}\text { Görsel } \\
\text { İran'da } \\
\text { yaşanan } \\
\text { yangının } \\
\text { ardından } \\
\text { kaydedilmiş. }\end{array}$ & $\begin{array}{l}\text { Hatalı } \\
\text { ilişskilendirme }\end{array}$ & $\begin{array}{l}\text { Montessori } \\
\text { Kulubu, aldı. } \\
30 / 07 / 2021\end{array}$ & $\begin{array}{l}22.185 \\
\text { etkileşim }\end{array}$ & Instagram \\
\hline
\end{tabular}




\section{MEDIAJ}

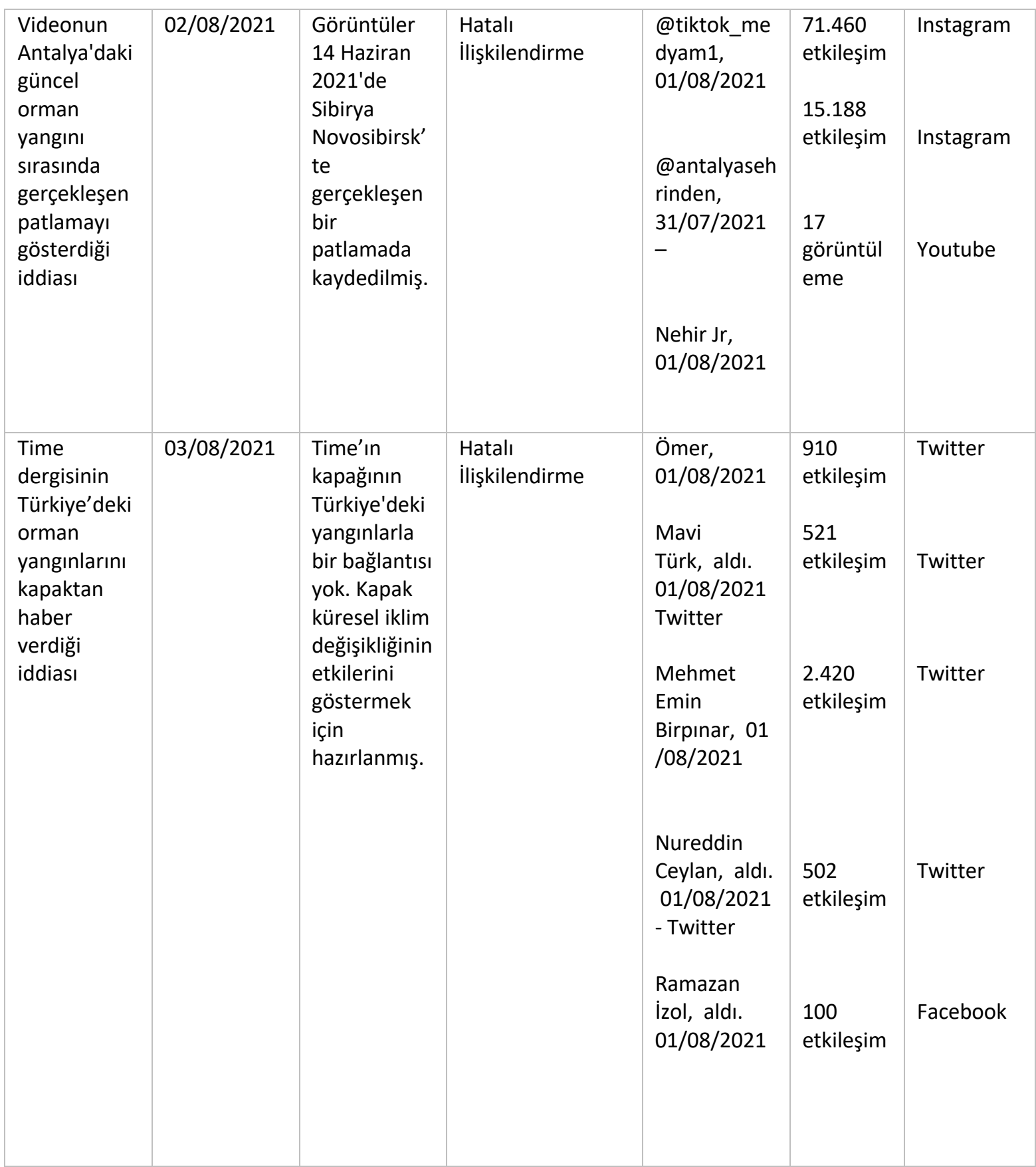




\section{MEDIAJ}

\begin{tabular}{|c|c|c|c|c|c|c|}
\hline $\begin{array}{l}\text { Videonun } \\
\text { PKK'nın } \\
\text { güncel } \\
\text { yangınları } \\
\text { üstlendiğini } \\
\text { gösterdiği } \\
\text { iddiası }\end{array}$ & $03 / 08 / 2021$ & $\begin{array}{l}\text { Video ilk kez } \\
2019 \text { yılında } \\
\text { paylaşılmış. } \\
\text { Videonun } \\
\text { Temmuz } \\
2021 \\
\text { yangınlarıyla } \\
\text { ilişkisi yok. } \\
\text { Video } \\
\text { örgütün } \\
\text { farkı } \\
\text { eylemleriyle } \\
\text { alakalı. }\end{array}$ & $\begin{array}{l}\text { Hatalı } \\
\text { Iliş̧kilendirme }\end{array}$ & $\begin{array}{l}\text { Bir Deli } \\
\text { Yazıyor., } \\
\text { 31/07/2021- } \\
\text { SOKAĞIN } \\
\text { KALBi, } \\
31 / 07 / 2021 \\
- \\
\text { Getto Yusuf, } \\
31 / 07 / 2021 \\
-\end{array}$ & $\begin{array}{l}\begin{array}{l}2.325 \\
\text { etkileşim }\end{array} \\
\begin{array}{l}1.660 \\
\text { etkileşim }\end{array}\end{array}$ & $\begin{array}{l}\text { Youtube } \\
\text { Youtube }\end{array}$ \\
\hline & & & & $\begin{array}{l}\text { TiKTOK } \\
\text { DijiTAL, } \\
31 / 07 / 2021 \\
- \\
\text { N. Selçuk } \\
\text { Kotan, } \\
31 / 07 / 2021 \\
\text { Celâli, } \\
31 / 07 / 2021 \\
-\end{array}$ & $\begin{array}{l}\begin{array}{l}13.107 \\
\text { etkileşim }\end{array} \\
\begin{array}{l}1.722 \\
\text { etkileşim }\end{array} \\
784 \\
\text { etkileşim }\end{array}$ & $\begin{array}{l}\text { Youtube } \\
\text { Twitter } \\
\text { Twitter }\end{array}$ \\
\hline $\begin{array}{l}\text { Turizmi } \\
\text { Teşvik } \\
\text { Kanunundak } \\
\text { i değişikliğin } \\
\text { yetki } \\
\text { sınırlandırm } \\
\text { asından } \\
\text { ibaret } \\
\text { olduğu } \\
\text { iddiası }\end{array}$ & 03/08/2021 & $\begin{array}{l}28 \text { Temmuz } \\
2021 \text { tarihli } \\
\text { Resmi } \\
\text { Gazete'de } \\
\text { yayımlanan } \\
\text { değişiklik } \\
\text { daha önce } \\
\text { Bakanlığın } \\
\text { önerisi ve } \\
\text { Bakanlar } \\
\text { Kurulu } \\
\text { kararıyla } \\
\text { turizm } \\
\text { merkezi } \\
\text { niteliği } \\
\text { belirlenen } \\
\text { arazilerin } \\
\text { bundan } \\
\text { sonraCumhu } \\
\text { rbaşkanının } \\
\text { kararıyla } \\
\text { belirlenmesi } \\
\text { ni }\end{array}$ & Çarpıtma & $\begin{array}{l}\text { Mehmet } \\
\text { Nuri Ersoy, } \\
\text { 01/08/2021 } \\
\text { Mehmet } \\
\text { Nuri Ersoy, } \\
\text { 01/08/2021 } \\
\\
\text { @DikenliB, } \\
\text { 02/08/2021 } \\
-\end{array}$ & $\begin{array}{l}\begin{array}{l}8.334 \\
\text { etkileşim }\end{array} \\
185 \\
\text { etkileşim }\end{array}$ & $\begin{array}{l}\text { Twiter } \\
\text { Facebook } \\
\text { Twitter }\end{array}$ \\
\hline
\end{tabular}


MEDIIAJ

\begin{tabular}{|c|c|c|c|c|c|c|}
\hline & & öngörüyor. & & & & \\
\hline $\begin{array}{l}\text { Fotoğraftaki } \\
\text { nin THK'nın } \\
\text { tek yangın } \\
\text { söndürme } \\
\text { uçağı olduğu } \\
\text { iddiası }\end{array}$ & 03/08/2021 & $\begin{array}{l}\text { Karma / } \\
\text { Polonya } \\
\text { yapımı } \\
\text { Dromader } \\
\text { uçağı, hem } \\
\text { yangın } \\
\text { söndürme } \\
\text { hem de zirai } \\
\text { ilaçlama } \\
\text { maksatlı } \\
\text { kullanılıyor. } \\
\text { THK } \\
\text { envanterind } \\
\text { e yer alan } \\
\text { tek uçak tipi } \\
\text { bu değil. }\end{array}$ & belirtilmemiş & $\begin{array}{l}\text { Cemile } \\
\text { Taşdemir, } \\
\text { 01/08/2021 } \\
- \\
\text { Siyam } \\
\text { Öküzü, } \\
\text { 01/08/2021 } \\
\text { - }\end{array}$ & $\begin{array}{l}\begin{array}{l}3.506 \\
\text { etkileşim }\end{array} \\
189 \\
\text { etkileşim }\end{array}$ & $\begin{array}{l}\text { Twitter } \\
\text { Twitter }\end{array}$ \\
\hline $\begin{array}{l}\text { Videonun } \\
\text { Datça'da } \\
\text { yangın } \\
\text { çıkarmak } \\
\text { için ormanlık } \\
\text { alana } \\
\text { bırakılan } \\
\text { torpilleri } \\
\text { gösterdiği } \\
\text { iddiası }\end{array}$ & 03/08/2021 & $\begin{array}{l}\text { Datça'nın } \\
\text { Aktur Tatil } \\
\text { Sitesi } \\
\text { yakınında } 29 \\
\text { Temmuz'da } \\
\text { çıkan } \\
\text { yangından } \\
\text { sonra } \\
\text { jandarma } \\
\text { soruşturma } \\
\text { başlattı. } \\
\text { Görgü } \\
\text { tanıklarının } \\
\text { üzerine dört } \\
\text { çocuk } \\
\text { gözlem } \\
\text { altına alındı. } \\
\text { Pedagog } \\
\text { eşliğinde } \\
\text { dinlenen } \\
\text { çocuklar } \\
\text { yangın } \\
\text { çıkarmak } \\
\text { değil, oyun } \\
\text { oynamak } \\
\text { için bölgeye } \\
\text { torpil } \\
\text { götürdükleri } \\
\text { ni belirtti. }\end{array}$ & $\begin{array}{l}\text { Çarpıtma } \\
\text { Hatalı } \\
\text { Illişkilendirme }\end{array}$ & $\begin{array}{l}\text { Vedat } \\
\text { Yenerer, } \\
\text { 02/08/2021 } \\
\text { ÇEBi, aldı. } \\
\text { 03/08/2021 } \\
\text { - } \\
\text { @ltush, } \\
\text { 03/08/2021 } \\
- \\
\text { hermes, } \\
\text { 03/08/2021 } \\
-\end{array}$ & $\begin{array}{l}\begin{array}{l}3.162 \\
\text { etkileşim }\end{array} \\
274 \\
\text { etkileşim }\end{array}$ & $\begin{array}{l}\text { Twitter } \\
\text { Twitter } \\
\text { Twitter } \\
\text { Twitter }\end{array}$ \\
\hline
\end{tabular}


MEDIAJ

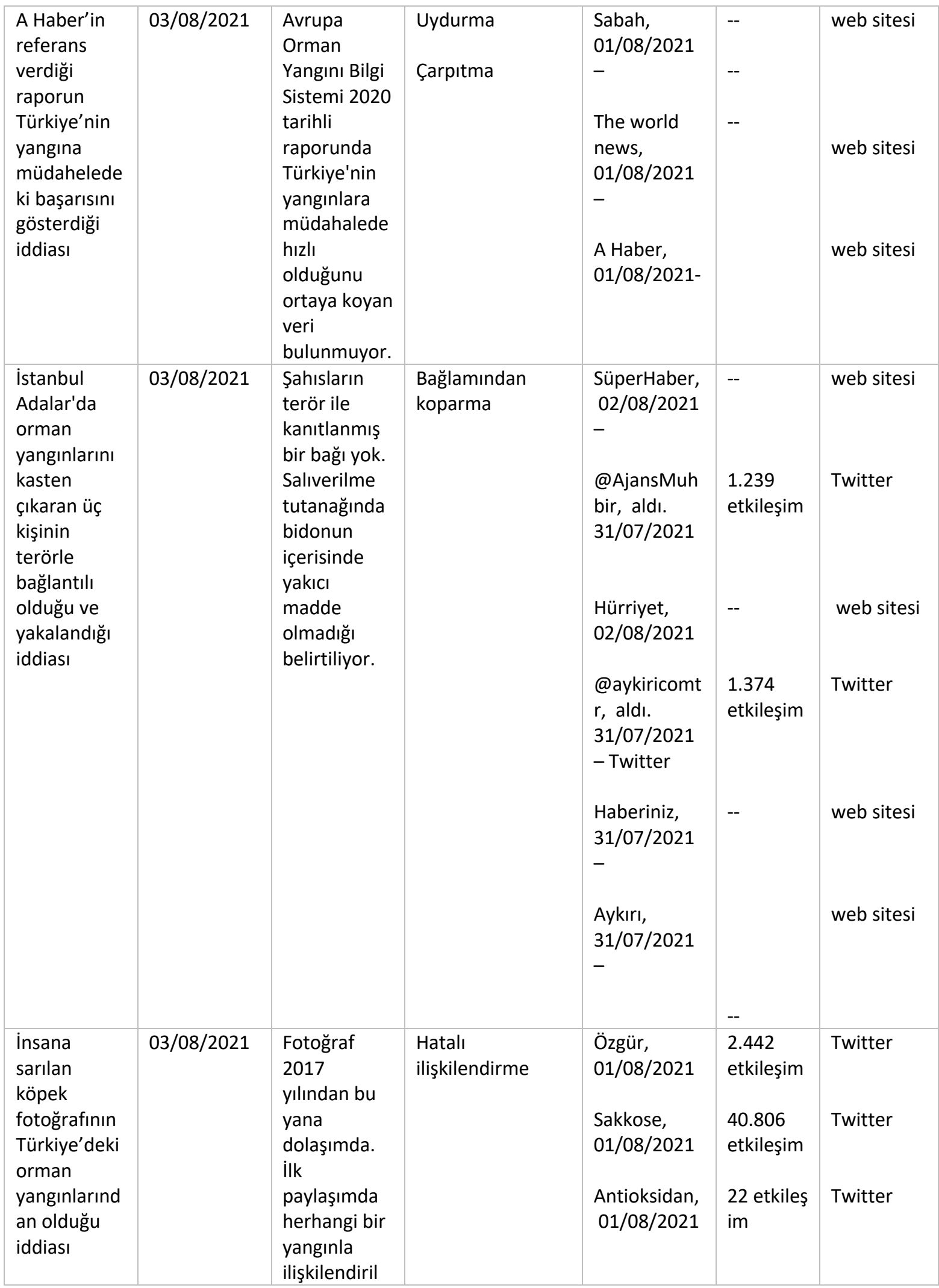




\begin{tabular}{|c|c|c|c|c|c|c|}
\hline & & memiş. & & $\begin{array}{l}\text { Metin du, } \\
01 / 08 / 2021 \\
\text { Nrcnmr, } \\
\text { 01/08/2021 } \\
\text { Çebi, } \\
\text { 01/08/2021 } \\
\text { Bulcahan, } \\
\text { 01/08/2021 }\end{array}$ & $\begin{array}{l}\begin{array}{l}138 \\
\text { etkileşim }\end{array} \\
196 \\
\text { etkileşim } \\
98 \\
\text { etkileşim } \\
847 \\
\text { etkileşim }\end{array}$ & $\begin{array}{l}\text { Twitter } \\
\text { Twitter } \\
\text { Twitter } \\
\text { Twitter }\end{array}$ \\
\hline $\begin{array}{l}\text { Mevcut } \\
\text { kızılçam } \\
\text { ormanlarının } \\
\text { ABD } \\
\text { yardımlarıyla } \\
\text { dikildiği } \\
\text { iddiası }\end{array}$ & 04/08/2021 & $\begin{array}{l}\text { Çamlar } 23 \\
\text { milyon yıldır } \\
\text { Anadolu'da } \\
\text { yaşıyor ve } \\
\text { evrimleşiyor. } \\
\text { Türkiye'de } \\
\text { doğal olarak } \\
\text { yetişen beş } \\
\text { çam türü } \\
\text { var, } \\
\text { bunlardan } \\
\text { biri de } \\
\text { kızılçam }\end{array}$ & Uydurma & $\begin{array}{l}\text { Sözcü } \\
\text { Gazetesi, } \\
02 / 08 / 2021 \\
\text { - web sitesi } \\
\text { Haber } \\
\text { Gazetesi, } \\
\text { 27/09/2019 } \\
\text { - web sitesi }\end{array}$ & & $\begin{array}{l}\text { Web sitesi } \\
\text { Web sitesi }\end{array}$ \\
\hline $\begin{array}{l}\text { Görüntülerin } \\
\text { Alanya } \\
\text { Güzelbahçe' } \\
\text { de lazerli } \\
\text { saldırı } \\
\text { sonucu çıkan } \\
\text { orman } \\
\text { yangınını } \\
\text { gösterdiği } \\
\text { iddiası }\end{array}$ & $04 / 08 / 2021$ & $\begin{array}{l}\text { Videoda } \\
\text { karşı ateş } \\
\text { uygulaması } \\
\text { yapılıyor. } \\
\text { İstanbul } \\
\text { Üniversitesin } \\
\text { den bir } \\
\text { öğretim } \\
\text { görevlisi de } \\
\text { görüntülerin } \\
\text { karşı ateş } \\
\text { uygulamasın } \\
\text { I gösterdiğini } \\
\text { söyledi. }\end{array}$ & $\begin{array}{l}\text { Hatalı } \\
\text { ilişkilendirme }\end{array}$ & $\begin{array}{l}\text { @84c23938 } \\
49 e 40 f, \text { aldı } \\
\text { 03/08/2021 } \\
- \\
\text { @ozhak198 } \\
\text { 5, aldı. } \\
\text { 03/08/2021 } \\
\text { @CemilCan5 } \\
\text { 834, aldı. } \\
\text { 02/08/2021 } \\
\text { TC Yıldıray } \\
\text { Yıldırım, } \\
\text { 02/08/2021 } \\
- \\
\text { @CDorukE, } \\
\text { 02/08/2021 } \\
- \\
\text { @mkalyonc } \\
\text { uoglu1,. } \\
\text { 02/08/2021 }\end{array}$ & $\begin{array}{l}\begin{array}{l}2.206 \\
\text { etkileşim }\end{array} \\
225 \\
\text { etkileşim } \\
2.122 \\
\text { etkileşim }\end{array}$ & $\begin{array}{l}\text { Twitter } \\
\text { Twitter }\end{array}$ \\
\hline
\end{tabular}




\section{MEDIIAJ}

\begin{tabular}{|c|c|c|c|c|c|c|}
\hline $\begin{array}{l}\text { Manavgat'ta } \\
\text { itfaiyecilerin } \\
\text { yangından } \\
\text { kurtarılan } \\
\text { koalaya su } \\
\text { verdiğini } \\
\text { gösterdiği } \\
\text { öne sürülen } \\
\text { video }\end{array}$ & $04 / 08 / 2021$ & $\begin{array}{l}\text { Itfaiyecilerin } \\
\text { koalaya su } \\
\text { verdiği } \\
\text { görüntüler } \\
2019 \\
\text { Avustralya } \\
\text { yangınından. }\end{array}$ & $\begin{array}{l}\text { Hatalı } \\
\text { ilişkilendirme }\end{array}$ & $\begin{array}{l}\text { Musti_1905, } \\
04 / 08 / 2021\end{array}$ & $\begin{array}{l}111.400 \\
\text { etkileşim }\end{array}$ & Tiktok \\
\hline $\begin{array}{l}\text { Hırvatistan'd } \\
\text { an gelen } \\
\text { uçağın } \\
\text { THK'nin ateş } \\
\text { kuşlarıyla } \\
\text { aynı model } \\
\text { olduğu } \\
\text { iddiası }\end{array}$ & $04 / 08 / 2021$ & $\begin{array}{l}\text { Ateş kuşu } \\
\text { ismiyle } \\
\text { anılan } \\
\text { uçakların } \\
\text { modeli CL- } \\
215 . \\
\text { Hırvatistan'ı } \\
\text { n gönderdiği } \\
\text { uçağın } \\
\text { modeli CL- } \\
415 . \\
\text { CL-415, CL- } \\
215 \text { ten } \\
\text { geliştirilmiş } \\
\text { üst model } \\
\text { bir yangın } \\
\text { söndürme } \\
\text { uçağı. }\end{array}$ & $\begin{array}{l}\text { Hatalı } \\
\text { ilişkilendirme }\end{array}$ & $\begin{array}{l}\text { Av. Alpay } \\
\text { Antmen, } \\
\text { 03/08/2021 } \\
\text { Atilla Torgay } \\
\text { 03/08/2021 } \\
\text { Dorota, } \\
\text { 03/08/2021 } \\
\text { Basia } \\
\text { EMFC, } \\
\text { 03/08/2021 }\end{array}$ & $\begin{array}{l}\begin{array}{l}58.000 \\
\text { etkileşim }\end{array} \\
33 \\
\text { etkileşim } \\
18 \\
\text { etkileşim }\end{array}$ & $\begin{array}{l}\text { Twitter } \\
\text { Twitter } \\
\text { Twitter } \\
\text { Twitter }\end{array}$ \\
\hline $\begin{array}{l}\text { Videonun } \\
\text { Türkiye'deki } \\
\text { güncel } \\
\text { yangınlarda } \\
\text { alevlerden } \\
\text { tavşan } \\
\text { kurtaran } \\
\text { kişiyi } \\
\text { gösterdiği } \\
\text { iddiası }\end{array}$ & $05 / 08 / 2021$ & $\begin{array}{l}\text { Illk kez } 2017 \\
\text { yılında } \\
\text { paylaşılan } \\
\text { video } \\
\text { Kaliforniya'd } \\
\text { a yaşanan } \\
\text { orman } \\
\text { yangınından. }\end{array}$ & $\begin{array}{l}\text { Hatalı } \\
\text { ilişkilendirme }\end{array}$ & $\begin{array}{l}\text { @kazancisel } \\
\text { man, } \\
\text { 04/08/2021 } \\
\text { @MirayAras } \\
\text {, aldı. } \\
\text { 03/08/2021 } \\
\text { - Twitter } \\
\text { Futbolun } \\
\text { Eğlencesi, } 03 \\
\text { /08/2021- } \\
\text { Youtube } \\
\text { Yeniçağ } \\
\text { Gazetesi, } \\
\text { 04/08/2021 } \\
\text { - } \\
\text { @emineyesil } \\
72,\end{array}$ & $\begin{array}{l}\begin{array}{l}142 \\
\text { etkileşim }\end{array} \\
572 \\
\text { etkileşim }\end{array}$ & $\begin{array}{l}\text { Web sitesi } \\
\text { Twitter }\end{array}$ \\
\hline
\end{tabular}




\begin{tabular}{|c|c|c|c|c|c|c|}
\hline & & & & $\begin{array}{l}\text { 03/08/2021 } \\
@ \text { baris_oruc } \\
, 03 / 08 / 2021 \\
\\
@ H s e y i n S a b \\
\text { anc1,. } \\
04 / 08 / 2021 \\
-\end{array}$ & $\begin{array}{l}\begin{array}{l}565 \\
\text { etkileşim }\end{array} \\
95 \\
\text { etkileşim }\end{array}$ & $\begin{array}{l}\text { Twitter } \\
\text { Twitter }\end{array}$ \\
\hline $\begin{array}{l}\text { Dünyanın en } \\
\text { büyük } \\
\text { yangın } \\
\text { söndürme } \\
\text { uçağının } \\
\text { Türkiye'ye } \\
\text { geldiği } \\
\text { iddiası }\end{array}$ & $05 / 08 / 2021$ & $\begin{array}{l}\text { Görüntüler } \\
2018 \text { yılında } \\
\text { ABD'de } \\
\text { kaydedilmiş. } \\
\text { Supertanker } \\
\text { olarak } \\
\text { bilinen } \\
\text { uçaklar şu } \\
\text { anda } \\
\text { Türkiye'de } \\
\text { kullanılmıyor }\end{array}$ & $\begin{array}{l}\text { Hatalı } \\
\text { ilişkilendirme }\end{array}$ & $\begin{array}{l}\text { Benaress1, } \\
\text { 03/08/2021 } \\
-\end{array}$ & $\begin{array}{l}148.000 \\
\text { etkileşim }\end{array}$ & Tiktok \\
\hline $\begin{array}{l}\text { Muğla'daki } \\
\text { yangının } \\
\text { ancak otel } \\
\text { sınırına } \\
\text { gelince } \\
\text { durdurulduğ } \\
\text { u iddiası }\end{array}$ & 08/08/2021 & $\begin{array}{l}\text { Güvercinlik } \\
\text { yangını sekiz } \\
\text { arazöz, altı } \\
\text { itfaiye aracı } \\
\text { ve } 40 \text { orman } \\
\text { işçisinin } \\
\text { çabalarıyla } \\
\text { söndürüldü. } \\
\text { Ayrıca otelin } \\
\text { birçok } \\
\text { noktasındaki } \\
\text { kendi } \\
\text { hidrant } \\
\text { sistemiyle } \\
\text { yangının } \\
\text { otele } \\
\text { sıçramasının } \\
\text { önüne } \\
\text { geçildi. }\end{array}$ & Çarpıtma & $\begin{array}{l}\text { galATAsarayl } \\
1, \\
30 / 07 / 2021 \\
\text { Seyit } \\
\text { Tosun, } \\
30 / 07 / 2021 \\
\text { Cem Cemal } \\
\text { Çobanoğlu, } \\
30 / 07 / 2021 \\
\\
\text { iskender } \\
\text { baydar, } \\
30 / 08 / 2021 \\
\\
\text { emrah isn't } \\
\text { scandinavian } \\
04 / 08 / 2021 \\
\text { Ekoloji } \\
\text { Radarı, } \\
30 / 07 / 2021 \\
\text { Ayşe } \\
\text { Aydoğdu, . } \\
04 / 08 / 2021\end{array}$ & $\begin{array}{l}\begin{array}{l}376 \\
\text { etkileşim }\end{array} \\
1.067 \\
\text { etkileşim }\end{array}$ & $\begin{array}{l}\text { Twitter } \\
\text { Twitter } \\
\text { Twitter } \\
\text { Twitter }\end{array}$ \\
\hline
\end{tabular}




\section{MEDIAJ}

\begin{tabular}{|c|c|c|c|c|c|c|}
\hline & & & & $\begin{array}{l}\text { Oğuz, } \\
04 / 08 / 2021\end{array}$ & $\begin{array}{l}846 \\
\text { etkileşim }\end{array}$ & Twitter \\
\hline $\begin{array}{l}\text { Yunanistan'ı } \\
\mathrm{n} \text { yangın } \\
\text { söndürme } \\
\text { uçağı } \\
\text { filosunu } \\
\text { gösterdiği } \\
\text { öne sürülen } \\
\text { fotoğraf }\end{array}$ & $09 / 08 / 2021$ & $\begin{array}{l}\text { Karma/ } \\
\text { Uçaklar } \\
\text { Yunanistan'ı } \\
\text { n yangınla } \\
\text { mücadele } \\
\text { hava } \\
\text { filosunda yer } \\
\text { alıyor. } \\
\text { Ancak } \\
\text { Yunanistan } \\
\text { filosu yalnız } \\
\text { bu } \\
\text { uçaklardan } \\
\text { ibaret değil. } \\
\text { Filoda 11 } \\
\text { adet CL-215 } \\
\text { ile yedi adet } \\
\text { CL-415 de } \\
\text { var. }\end{array}$ & $\begin{array}{l}\text { Hatalı } \\
\text { İlişkilendirme }\end{array}$ & $\begin{array}{l}\text { Özgür } \\
\text { Adam, } \\
\text { 09/08/2021 } \\
\text { Nejat } \\
\text { Özonay, } \\
\text { 09/08/2021 }\end{array}$ & $\begin{array}{l}\begin{array}{l}1.299 \\
\text { etkileşim }\end{array} \\
\begin{array}{l}1.970 \\
\text { etkileşim }\end{array}\end{array}$ & $\begin{array}{l}\text { Twitter } \\
\text { Twitter }\end{array}$ \\
\hline $\begin{array}{l}\text { Fotoğrafın } \\
\text { Türkiye'deki } \\
\text { güncel } \\
\text { yangınlardan } \\
\text { olduğu } \\
\text { iddiası }\end{array}$ & $09 / 08 / 2021$ & $\begin{array}{l}\text { Video } 17 \\
\text { Mart } 2021 \\
\text { tarihinde } \\
\text { TikTok'a } \\
\text { yüklenmiş. } \\
\text { Video } \\
\text { Teksas'ta } \\
\text { faaliyet } \\
\text { gösteren bir } \\
\text { şirketin } \\
\text { çalışanları } \\
\text { tarafından } \\
\text { çekilmiş. }\end{array}$ & $\begin{array}{l}\text { Hatalı } \\
\text { İlişkilendirme }\end{array}$ & $\begin{array}{l}\text { Siyah, } \\
06 / 08 / 2021\end{array}$ & $\begin{array}{l}29 \text { bin } \\
600 \\
\text { etkileşim }\end{array}$ & Twitter \\
\hline $\begin{array}{l}\text { Orman } \\
\text { yangınlarınd } \\
\text { a sadece } \\
\text { çam } \\
\text { ailesinden } \\
\text { ağaçların } \\
\text { yandığı } \\
\text { iddiası }\end{array}$ & $11 / 08 / 2021$ & $\begin{array}{l}\text { Sadece çam } \\
\text { ağaçları } \\
\text { değil, iğne } \\
\text { yapraklı } \\
\text { familyasında } \\
\text { ki diğer } \\
\text { ağaçlar da } \\
\text { epey yanıcı. } \\
\text { Çam ailesi } \\
\text { dışında da } \\
\text { kolay alev } \\
\text { alabilen } \\
\text { birçok tür }\end{array}$ & Çarpıtma & $\begin{array}{l}\text { Soner } \\
\text { Güney, } \\
\text { 02/08/2021 } \\
\text { - }\end{array}$ & $\begin{array}{l}34,000 \\
\text { etkileşim }\end{array}$ & Facebook \\
\hline
\end{tabular}




\begin{tabular}{|l|l|l|l|l|}
\hline & bulunuyor. & & \\
\hline Hatta bazı & & & \\
meyve & & & \\
ağaçları da & & & \\
kolay & tutuşabiliyor & & \\
\hline
\end{tabular}

Yukarıda tablodan anlaşılacağı gibi etkileşimin en fazla olduğu sosyal mecra Twitter'dır. Twitter'da, 68 farklı hesap tarafından konu hakkında paylaşım yapılmıştır. Twitter'dan sonrasında 5 farklı hesaptan yapılan paylaşımlarla Youtube, yine 5 farklı hesaptan yapılan paylaşımlarla Facebook ve 3 farklı hesaptan yapılan paylaşımlarla Instagram ve 2 hesaptan yapılan paylaşımlarla TikTok yer almaktadır.

Araştırmadan elde edilen bir diğer bulgu ise dezenformasyon türleri ile ilgilidir. Dezenformasyonun en yaygın olarak kendini gösterdiği yedi tür bulunmaktadır. Bunlar parodi, çarpıtma, hatalı ilişkilendirme, bağlamından koparma, uydurma, taklit ve manipülasyondur. Bu çalışmada Teyit.org tarafından yalan / yanlış olduğu belirlenen 25 haberin 18 tanesinin hatalı ilişkilendirme, dezenformasyon türünde olduğu görülmektedir. Hatalı ilişkilendirmeden sonra karşımıza en çok çıkan dezenformasyon türü çarpıtma olmuştur. Bu dezenformasyon türü de hatalı ilişkilendirme ile benzer özellikler taşımaktadır ve içeriklerin gerçek anlamından koparıldığı görülmektedir. En son uydurma ve bağlamından koparma türü gelmektedir.

Araştırmada yanlış iletilerin öz kaynaklarının, genelde dünyanın değişik bölgelerinde gelişen konuya yakın olaylar olduğu da saptanmıştır.

\section{SONUÇ}

Yeni medya platformları ve teknolojileri günümüz sıradan kitlelerini içeriği hem üreten hem de tüketen kullanııılara dönüştürmüştür. Bu durum ilk görünüşü ile kullanıcılara yaratıcı içerikler üretmesi, özgürce istedikleri içeriklere ulaşabilmesi gibi bir anlayış yaratsa da yeni medyanın sahte içerik/yalan haber tehdidini de doğurabilmektedir. Post-truth kapsamında yalan, yanlı, sahte içerik ve haberlerin kolayca yeni medyada dolaşıma sokulması ve diğer kullanıcılar tarafından bunların sürekli tüketilerek paylaşılması ağ toplumuna özgü bir bağlantılıık yaratsa da aslında sorunlu/zarar verici konuma geçebilmektedir.

Yalan habere/içeriklere dair paylaşımların sosyal medyada çok fazla üretildiği ve tüketildiği bir konu da Türkiye'de 28 Temmuz 2021 tarihinde başlayan orman yangınlarına dair olmuştur. Bu çalışmada 29 Temmuz - 11 Ağustos 2021 tarihleri arasında Türkiye'de çıkan yangınlarla ilgili sosyal medyada dolaşıma sokulan ve Teyit.org tarafından yalan/yanlış haber olduğu tespit edilen toplam 25 haber incelenmiştir.

Bu haberler sadece Teyit.org'nin incelediği ve yanlışlığını onayladığı paylaşımlardır. Bu kadar kısa bir zaman diliminde böylesine önemli bir toplumsal kriz ve doğal afet anında yayılan yalan haberler toplumun içinde bulunduğu negatif durumu daha da derinleştirirken, çözüm 
üretmekten çok sorunu büyütebilmektedir.

Yapılan inceleme doğrultusunda sosyal mecraların yalan haber dolaşımında etkili olduğu düşünülmektedir. Bu düşüncenin alt yapısını iletilerin aldığı etkileşim oranları oluşturmaktadır. Ünal ve Taylan (2017), Çömlekçi (2019), Erkan ve Ayhan (2018) sosyal medyada bir çok kişinin iletinin doğruluğunu sorgulama kaygılarının olmadığını ileri sürmüşlerdir.

Dezenformasyonun türü ne olursa olsun sosyal medyanın bu durumu gerçekleştirmede işleri çok kolaylaştırdığı ve hızlı yayılmasına oldukça elverişli bir zemin hazırladığı yapılmış diğer çalışmalar gibi bu çalışmada da durumu doğrular nitelik taşımaktadır.

Wardle (2017) oluşturulan ve paylaşılan farklı içerik türlerini, bu içeriği oluşturanların motivasyonlarını ve bu içeriğin yayılma yollarını bilmenin ve bunları ayırmanın mevcut bilgi ekosistemini anlamak için önemli bir adım olduğunu ifade etmektedir. Bu kapsamda doğrulama platformları yeni medyanın eşik bekçiliği görevi üstlenerek yalan haberin/içeriğin erken tespiti ile geniş kitlelere ulaşmadan önce yayılmasını önlemede erken bir uyarı sistemi gibi çalışabilmektedir. Bu durum demokratik bir toplumda, kamuoyunun bilgi alma hakkını sağlamakta ve konunun kamusal alanda tartışılmasını doğurabilmektedir.

Elzinga'nın (2021) ifade ettiği gibi sahte içerikleri üretip, tüketen bireylerin, böyle bir bilişsel yetersizliğini açıklamak için kişinin epistemik kusuru olduğunu varsaymak eksik kalabilmektedir. Kişinin bilme yetersizliği, ait olduğu sosyal gruba üyelik yoluyla üretilmekte ve sürdürülmektedir (s.42). Geeng, Yee ve Roesner'ın (2020) söylemiyle homojen bir yankı odasına gömülü olan bireyin yanlış bilgi ile nasıl etkileşime girdiği konusunda daha fazla araştırmaya ihtiyaç vardır.

Bu düşünceyle sahte içerik ve haberlere karşı duruşta medya okuryazarlığı öne çıkmaktadır. Örneğin BBC (2017), Facebook'un sahte haberleri tespit etmek için, başlıklara şüpheyle yaklaşmayı, URL'nin incelenmesini, kaynağı araştırılmasını, içeriğin normalin dışında farklı formatlarda verildiğinde dikkat edilmesini, fotoğrafların ayrıntılı incelenmesini, tarihin kontrol edilmesini, kanıtları kontrol edilmesini, mümkünse diğer raporlara bakılmasını, içeriğin şaka olabileceğinin düşünülmesine ve bazı hikayeler kasıtlı olarak yanlış (hiciv) verilebileceğine dikkat etmeyi önermektedir.

\section{KAYNAKÇA}

AFAD (18.08.2021) Doğal afetler. https://www.afad.gov.tr/afadem/dogal-afetler.

Allcott, H., \& Gentzkow, M. (2017) Social media and fake news in the 2016 election. Journal of Economic Perspectives, 31 (2): 211-236. doi: 10.1257/jep.31.2.211

Andersen, J., \& Søe, S. O. (2019) Communicative actions we live by: The problem with factchecking, tagging or flagging fake news - the case of Facebook European Journal of Communication, 126-139 https://doi.org/10.1177/0267323119894489 


\section{MEDIIAJ}

Ayhan, A., \& Gülsüm, E. (2018) Siyasal iletişimde dezenformasyon ve sosyal medya: Bir doğrulama platformu olarak Teyit.Org. Akdeniz Üniversitesi İletişim Fakültesi Dergisi, (AKiL) Kasım (30) s. 201-223

Bahar, A. (2020). Polislik perspektifinden dijital misenformasyon ve dezenformasyon: covid-19 örnek olayı bağlamında bir analiz. OPUS Uluslararası Toplum Araştırmaları Dergisi,16(30), 2760- 2794.

Barthel, M., Mitchell, A., \& Holcomb, J. (2016). Many Americans believe fake news is sowing confusion. Pew Research Center, 15, 12. Available at: https://www.journa lism.org/2016/12/15/many-americans-believe-fake-news-issowing-confusion/ (Accessed 14 April 2020)

Besli, N., \& M. E. Tenekeci, (2020) "Uydu verilerinden karar ağaçları kullanarak orman yangını tahmini", DUJE, 11, (3), 899-906, Oxford Living Dictionaries. (2021) "post-truth." https:// en.oxforddictionaries.com/definition/post-truth

BBC (2017). Facebook publishes fake news ads in uk papers. (2017, 8 Mayıs). http://www.bbc.com/news/technology-39840803

Cumhuriyet (04.08.2021). Orman yangınları: Hangi iddialar ortaya atıldı, yetkililer ne yanıt verdi? https://www.cumhuriyet.com.tr/haber/orman-yanginlari-hangi-iddialar-ortaya-atildiyetkililer-ne-yanit-verdi-1857814

Çimen, Ü. (2020). Yöndeşen medyayı doğru algılama bağlamında medya okuryazarlı̆ı̆ eğitimi. Karadeniz Teknik Üniversitesi İletişim Araştırmaları Dergisi, 10(1), 117-137. https://dergipark.org.tr/tr/pub/e-kiad/issue/55208/691116

David P., \& Reed, D. P. (February, 2001) From the magazine the law of the pack. https://hbr.org/search?term=david\%20p.\%20reed

Dogrulukpayi.com. (17.10.2021). http 7 https://www.dogrulukpayi.com/ Hakkimizda

Elzinga, B. 2021. "Echo chambers and crisis epistemology: a reply to santos." Social Epistemology Review and Reply Collective 10 (1): 41-47. https://wp.me/p1Bfg0-5Dm.

Geeng, C., Yee, S., \& Roesner, F. (2020). Fake news on Facebook and Twitter: investigating how people (don't) investigate CHI '20: Proceedings of the $2020 \mathrm{CHI}$ Conference on Human Factors in Computing Systems April 2020 Pages 114https://doi.org/10.1145/3313831.3376784

Güven, A. (2020). Hakikatin yitimi olarak post-truth: Bir kavramsallaştırma denemesi. Insan ve İnsan, $7(23), 20-36$.

Haberler.com (02.08.2021). https://www.haberler.com/nerede-yangin-var-yanginlarnerede-cikti-14296098-haberi/

İnceoğlu, Y. (2007). Medyayı doğru okumak. N. Türkoğlu \& M. Cinman Şimşek (Ed.), Medya Okuryazarlı̆̆ı. Kalemus.

Journo.com (17.07.2020). Dezenformasyon nedir? Sosyal medya, savaş meydanı oldu. 
https://journo.com.tr/dezenformasyon-nedir

Karadağ, H., \& Ayten, A. (2020). Comparative study of verification/fact-checkıng organizatons in Turkey: Dogrulukpayi.com and Teyit.org. Motif Akademi Halkbilimi Dergisi, 13(29), 483-501.

Karaduman, S. (2019). Yeni medya okuryazarlığı: yeni beceriler/olanaklar/riskler. Erciyes İletişim Dergisi, 6(1), 683-700. 10.17680/erciyesiletisim.484193

Karakaş, O., \& Doğru, Y. B. (2021). Covid-19 aşılarına yönelik üretilen yeni medya içeriklerinin post- truth kavramı bağlamında analizi. Asya Studies-Academic Social Studies / Akademik Sosyal Araştırmalar, 5(16), 163-182.

Kavaklı, N. (2019).Yalan haberle mücadele ve internet teyit/doğrulama platformları Erciyes İletişim Dergisi. 6, (1), 663-682

Krause,M. N., Freiling, I., Beets B., \& Brossard, D. (2020) Fact-checking as risk communication: the multi-layered risk of misinformation in times of COVID-19, Journal of Risk Research, 23:7-8, 1052-1059, DOI: 10.1080/13669877.2020.1756385 https://doi.org/10.1080/13669877.2020.1756385

Malumatfurus.org. (17.10.2021). http 6 https://www.malumatfurus.org/hakkinda/

Meyer, R. (2017). The rise of progressive 'fake news'. The Atlantic. https://www.theatlantic.com/technology/archive/2017/02/viva-la-resistancecontent/515532/

Naeem, S.B., \& Bhatti, R (2020). The Covid-19 'infodemic': a new front for information professionals. Health Information \& Libraries Journal June 2020 DOI: 10.1111/hir.12311

Oxford Living Dictionaires (03.12.2021) Oxford Living Dictionaries. https://www.oxfordlearnersdictionaries.com/definition/english/post-truth

Posos Devrani, A. E. (2020). Yeni medya okuryazarlı̆̆ının eğitim sistemindeki yeri: ilkokul ve ortaokul öğretmenlerinin yaklaşımı. Ege Üniversitesi İletişim Fakültesi Medya ve İletişim Araştırmaları Hakemli E-Dergisi, (6), 23-38.

Rhodes, S.C. (2020). Filter bubbles, echo chambers, and fake news: how social media conditions individuals to be less critical of political misinformation. political communication. https://www.tandfonline.com/doi/epub/10.1080/10584609.2021.1910887?needaccess=true

Sak, R., Şahin Sak, i. T., Öneren Şendil, Ç., \& Nas, E. (2021). Bir araştırma yöntemi olarak doküman analizi. Kocaeli Üniversitesi Eğitim Dergisi, 4(1), 227-250. http://doi.org/10.33400/kuje.843306

Sezen, D. (2011). Katılımcı Kültürün OluG̣umunda Yeni Medya Okuryazarlığı: ABD ve Türkiye Örnekleri [Doktora Tezi, İstanbul Üniversitesi]. YÖK Ulusal Tez Merkezi http://nek.istanbul.edu.tr:4444/ekos/TEZ/48921.pdf

Shu K., Mahudeswaran, D., Wang, S., Lee, D., \& Liu.H. (2020) Big Data. Volume: 8 (3), 171188. http://doi.org/10.1089/big.2020.0062 
Shu, K., Wang, S., \& Liu, H. (2018) Understanding user profiles on social media for fake news Det. 2018 IEEE Conference on Multimedia Information Processing and Retrieval DOI 10.1109/MIPR.2018.00092

Sözcü.com (04.08.2021) https://www.sozcu.com.tr/2021/gundem/sosyal-medyada-yeralan-orman-yanginlari-yalanlari-6573054/

Tandoc, E.C., Lim, Z.W., \& Ling, R. (2017). Defining "fake news" a typology of scholarly definitions. Digital Journalism, https://doi.org/10.1080/21670811.2017.1360143

Ünver, H.A. (2020). Türkiye'de doğruluk kontrolü ve doğrulama kuruluşları Siber Politikalar Dijital demokrasi. https://edam.org.tr/wp-content/uploads/2020/06/TürkiyedeDoğruluk-Kontrolü-ve-Doğrulama-Kuruluşları-Akın-Ünver.pdf

Vosoughi, S., Roy, D., \& Aral, S. (2018). The spread of true and false news online. Science, 359: 1146-1151.

Yolçu, N. (2018). Yeni medyanın yeni eşik bekçileri olarak haber doğrulama siteleri: Teyit. Org Örneği. 4. ICPESS (International Congress on Politic, Economic and Social Studies http://registericpess.org/index.php/ICPESS/article/view/1452 